\title{
Analisis Kendala Implementasi Pedoman Kendali Mutu Audit Aparat Pengawasan Intern Pemerintah Pada Inspektorat Daerah Kabupaten Bone Bolango
}

\author{
ISRAN UTIARAHMAN ${ }^{1}$, LINTJE KALANGI ${ }^{2}$, HENDRIK MANOSSOH ${ }^{3}$ \\ Program Magister Akuntansi, Fakultas Ekonomi dan Bisnis Universitas Sam Ratulangi \\ email :isranutiarahman@yahoo.co.id ${ }^{1}$
}

\begin{abstract}
Audit Quality Control Guidelines for Government Internal Auditors (APIP) are procedures and controls that must be performed by each APIP institutions including policies, procedures and control program. The guidelines must be compiled by APIP to ensure that audits are conducted in accordance with the Audit Standards of APIP. There are eight elements in the Guidelines. Those are the Strategic Plan Formulation; Quality Control of Audit Planning of APIP, Audit Plan and Program, Audit Supervision, Audit Implementation, Audit Reporting, Follow-Up of Audit Findings, and Administration and Human Resources. The purpose of this study is to analyze the constraints in implementing PKMA-APIP in the Regional Inspectorate Bone Bolango. This study also discusses the strategies and efforts to overcome those constraints in order to provide assurance and ensure that audits are conducted in accordance with auditing standards APIP. This is a qualitative case study research. Data were obtained through indepth interviews, observation and documentation. Validity and reliability were determined by triangulation. Results show that the Regional Inspectorate Bolango Bone regency in implementing PKMA-APIP not fully in accordance with PERMENPAN and RB 19 Year 2009 on Guidelines for Audit Quality Control-APIP. Codes were established from the transcriptions. Findings indicate that PKMA-APIP was partially implemented. It is caused by some obstacles: organizational commitment, Integrity Auditor, Human Resources and inadequacy of Structure Bureaucracy. Efforts have been conducte to improve its human resources by training, implementing integrity, supporting, building committed leadership including all controllers and estabish the control procedures in accordance with PKMA-APIP.
\end{abstract}

Keywords: Contraints, Quality Control, APIP.

Abstrak. Pedoman Kendali Mutu Audit APIP merupakan suatu prosedur dan reviu pengendalian yang harus dilakukan oleh setiap APIP yang meliputi kebijakan, prosedur dan program pengendalian yang wajib dipergunakan sebagai acuan bagi seluruh APIP guna memastikan bahwa audit yang dilaksanakan sesuai dengan Kode Etik APIP dan Standar Audit APIP. Terdapat delapan elemen yang diatur dalam PKMA-APIP ini, yaitu Penyusunan Rencana Strategis, Pengendalian Mutu Perencanaan Audit APIP, Pengendalian Mutu Penyusunan Rencana dan Program Kerja Audit, Pengendalian Mutu Supervisi Audit, Pengendalian Mutu Pelaksanaan Audit, Pengendalian Mutu Pelaporan Audit, Pengendalian Mutu Pemantauan Tindak Lanjut Hasil Audit, dan Pengendalian Mutu Tata Usaha dan Sumber Daya Manusia Tujuan dari penelitian ini adalah untuk menganalisis kendala Implementasi PKMA-APIP pada Inspektorat Daerah Kabupaten Bone Bolango serta upaya untuk mengatasinya agar dapat memberikan jaminan dan memastikan bahwa audit dilakukan sesuai standar audit APIP. Metode analisis yang digunakan adalah kualitatif dengan pendekatan studi kasus. Data kualitatif yang digunakan diperoleh melalui wawancara mendalam, observasi dan studi dokumentasi. Validitas dan reliabilitas data ditentukan dengan tringulasi data dan sumber. Selanjutnya data yang diperoleh dilakukan coding dan analisis data serta interpretasi dan penarikan kesimpulan. Hasil penelitian dan analisis menyatakan bahwa Inspektorat Daerah Kabupaten Bone Bolango dalam mengimplementasikan PKMA-APIP belum sepenuhnya sesuai dengan PermenPAN dan RB No.19 Tahun 2009 Tentang Pedoman Kendali Mutu Audit-APIP, karena masih terdapat beberapa kendala sepeti: Komitmen Organisasi, Integritas Auditor, Sumber Daya Manusia serta Struktur Birokrasi yang 
belum memadai. Upaya yang dapat dilakukan adalah Peningkatan Sumber daya manusia melalui diklat, membangun integritas, dukungan dan komitmen pimpinan dan seluruh personil pengawas serta membuat prosedur pengawasan sesuai dengan PKMA-APIP untuk dilaksanakan.

Kata Kunci: Kendala, Kendali Mutu, APIP

\section{Pendahuluan}

Kementerian Pendayagunaan Aparatur Negara dan Reformasi Birokrasi menetapkan Pedoman Kendali Mutu Audit-Aparat Pengawasan Intern Pemerintah (PKMA-APIP) melalui Peraturan Menteri Pendayagunaan Aparatur Negara dan Reformasi Birokrasi (Permenpan-RB) Nomor 19 Tahun 2009 guna memastikan dan memberikan jaminan yang memadai bahwa audit yang dilaksanakan telah sesuai dengan Standar Audit, Dalam PKMA-APIP ini sistem pengendalian mutu audit merupakan suatu prosedur dan reviu pengendalian yang harus dilakukan oleh setiap unit APIP yang meliputi kebijakan, prosedur dan program pengendalian sebagaimana tercantum pada standar audit APIP. Terdapat delapan elemen yang diatur dalam PKMA-APIP (Permenpan-RB) Nomor 19 Tahun 2009 yaitu Pedoman Penyusunan Rencana Strategis, Pengendalian Mutu Perencanaan Audit APIP, Pengendalian Mutu Penyusunan Rencana dan Program Kerja Audit, Pengendalian Mutu Supervisi Audit, Pengendalian Mutu Pelaksanaan Audit, Pengendalian Mutu Pelaporan Audit, Pengendalian Mutu Tindak Lanjut Hasil Audit, dan Pengendalian Mutu Tata Usaha dan Sumber Daya Manusia. Delapan elemen ini merupakan prosedur-prosedur yang digunakan untuk memastikan bahwa APIP telah memenuhi tanggung jawab profesionalnya kepada auditi maupun pihak lainnya.

Maksud disusunnya PKMA-APIP dalam Permenpan-RB Nomor 19 Tahun 2009 ini adalah untuk memecahkan berbagai masalah yakni ; (1) Ketidakefektifan pengawasan intern; (2) Proses audit yang tidak transparan; (3) Kualitas dan integritas pengendali tehnis dan pengendali mutu audit yang kurang memadai; (4) Pelaksanaan audit yang kurang terjamin mutunya sehingga tidak mencapai tujuan pelaksanaan audit; (5) Belum adanya Pedoman Kendali Mutu Audit APIP yang mendukung agar audit dapat berjalan lebih efisien dan efektif. Tujuannya adalah memastikan bahwa audit yang dilaksanakan oleh APIP sesuai dengan kode etik dan standar audit.

Selain itu (Andayani, 2009), pengendalian mutu juga dapat mencegah timbulnya masalah yang terjadi pada proses pelaksanaan audit terutama bagi instansi pengawasan intern pemerintah yang memiliki obyek pemeriksaan yang kompleks. Oleh karena itu, Aparat pengawas atau pemeriksa dituntut untuk semakin meningkatkan kualitas audit sesuai dengan tugas dan fungsinya dalam upaya menciptakan tata kelola keuangan yang baik. Pengendalian kualitas atau mutu audit merupakan hal yang penting untuk meminimalisasi penyimpangan yang terjadi selama proses audit berlangsung.

Berdasarkan laporan hasil kegiatan quality assurance penilaian mandiri kapabilitas APIP pada Inspektorat Kabupaten Bone Bolango oleh Badan Pengawasan Keuangan dan Pembangunan (BPKP) Perwakilan Provinsi Gorontalo Nomor 190 tanggal 24 Oktober Tahun 2016 menunjukkan bahwa Inspektorat Kabupaten Bone Bolango sedang menerapkan pengendalian mutu pengawasan untuk setiap penugasan berupa standar kendali mutu yang mempertimbangkan dan merujuk kepada Permenpan Nomor 19 Tahun 2009 tentang Pedoman Kendali Mutu Audit aparat pengawasan intern pemerintah.

Kondisi yang terjadi Inspektorat Daerah Kabupaten Bone Bolango masih mengalami beberapa permasalahan dalam mengimplementasikan Pedoman Kendali Mutu Audit-APIP, yang merupakan acuan bagi seluruh APIP dalam memastikan dan menjamin kualitas audit. Berdasarkan laporan hasil kegiatan quality assurance penilaian mandiri kapabilitas APIP pada Inspektorat Kabupaten Bone Bolango oleh Badan Pengawasan Keuangan dan Pembangunan (BPKP) Perwakilan Provinsi Gorontalo Nomor 190 tanggal 24 Oktober Tahun 2016 Dapat diidentifikasi beberapa gap (permasalahan) yang ada, yakni dimana terjadi suatu kondisi yang masih jauh dari harapan dan/atau belum sesuai dengan "kriteria" yang seharusnya terjadi. Beberapa gap tersebut antara lain sebagai berikut:

Pertama, partisipasi dan dukungan dari aparat pengawas untuk mengimplementasikan PKMA-APIP yang masih kurang. Karena belum melibatkan semua komponen yang ada di Inspektorat 
Kabupaten Bone Bolango baik pada jajaran pejabat struktural maupun pejabat fungsional. Hal ini berdasarkan penilaian quality assurance oleh BPKP pada Tahun 2016, bahwa Inspektorat Daerah Kabupaten Bone Bolango belum menyusun laporan hasil pengawasan yang sesuai dengan Pedoman Kendali Mutu Audit Aparat Pengawasan Intern Pemerintah.

Kedua, struktur birokrasi yang belum memadai dimana Inspektorat Daerah Kabupaten Bone Bolango belum tertib dalam tata kelola struktur birokrasi dalam mengimplementasikan PKMA-APIP yang berisi pedoman-pedoman guna menjamin kualitas audit, karena belum dituangkan dalam Standar Operasional Prosedur (SOP). sehingga berbagai fungsi dijalankan dengan sangat fleksibel. Hal ini juga yang masih menjadi permasalahan berdasarkan hasil penilaian quality assurance oleh BPKP pada tahun 2016, yakni belum adanya Standar Operasional Prosedur (SOP) pelaporan ikhtisar hasil pengawasan.

Ketiga, Pengelolaan sumber daya manusia (SDM) yang belum memadai, baik secara kuantitas maupun kualitas yaitu kurangnya pemahaman dan tanggungjawab auditor akan pentingnya kualitas audit yakni aparat pengawas yang belum memiliki kompetensi (keahlian dan pengetahuan) sehingga mengakibatkan pelaksanaan tugas pemeriksaan atau audit yang diberikan oleh pimpinan APIP tidak sesuai dengan tujuan yang ditetapkan.

Kondisi ini sesuai dengan hasil penilaian kegiatan quality assurance oleh BPKP pada tahun 2016, leveling APIP Inspektorat Kabupaten Bone Bolango berada pada Level 2 (dua). Terdapat permasalahan Pengelolaan SDM dimana siklus pengembangan pegawai mulai dari penetapan kompetensi yang dibutuhkan melalui kerangka kompetensi, identifikasi kompetensi melalui peta kompetensi, analisa jurang kompetensi, perencanaan diklat, pelaporan pelaksanaan diklat, hingga kembali ke pemutakhiran peta kompetensi harus diimplementasikan secara berkesinambungan.

Hasil penelitian Ismail, et al. (2008) menyimpulkan bahwa kendala dalam penerapan kendali mutu audit antara lain karena masalah pendelegasian tanggung jawab, efisiensi waktu dalam pengisian format dan checklist yang disyaratkan dan seringkali tidak dijawab secara tepat. Masalah lain yang muncul adalah pemahaman pegawai yang tidak memadai mengenai kendali mutu audit dan bagaimana penerapannya. SDM audit masih kurang baik kuantitas maupun kualitasnya.

Tujuan penelitian ini adalah menganalisis kendala implementasi Pedoman Kendali Mutu Audit Aparat Pengawasan Internal Pemerintah pada Inspektorat Daerah Kabupaten Bone Bolango, serta mengindentifikasi upaya untuk mengatasi kendala dalam implementasi PKMA-APIP pada Inspektorat Daerah Kabupaten Bone Bolango.

\section{Metode Penelitian}

Penelitian ini menggunakan metode penelitian kualitatif dengan pendekatan studi kasus sebagai desain penelitian berdasarkan alasan yaitu ingin menggali informasi mendalam untuk menyelidiki secara cermat, intensif dan terinci kendala implementasi PKMA-APIP serta upaya yang dilakukan pada Inspektorat Daerah Kabupaten Bone Bolango. Stake dalam Denzin dan Lincoln (2005:443) menyebukan "what can be learned from a single case?. Stake dan Yin dalam John W. Creswell (2014:42) menyatakan bahwa studi kasus merupakan salah satu penelitian kualitatif, dimana peneliti melakukan eksplorasi secara mendalam terhadap program, kejadian, proses, aktivitas terhadap satu atau lebih orang. Suatu kasus terikat oleh waktu dan aktivitas kemudian peneliti melakukan pengumpulan data secara mendatail dengan menggunakan berbagai prosedur pengumpulan data dan dalam waktu yang berkesinambungan.

\section{Model Analisis}

Model analisis dalam penelitian ini dikembangkan dengan menguraikan secara deskriptif terhadap fenomena yang menjadi permasalahan dalam mengimplementasikan PKMA-APIP yang dibatasi secara tematik ke dalam dua fokus penelitian, yaitu kendala implementasi PKMA-APIP dan upaya untuk mengatasi kendala tersebut. Kemudian berdasarkan pengorganisasian/kategorisasi data (coding) hasil penelitian, selanjutnya dilakukan analisis dengan cara membandingkan hasil penelitian dengan teori, konsep, peraturan dan penelitian terdahulu yang relevan untuk ditarik suatu kesimpulan dalam rangka menjawab setiap rumusan masalah. 
Kurangnya dukungan dan partisipasi aparat pengawas dalam mengimplementasikan PKMAAPIP; kurangnya integritas dalam pelaksanaan tugas pengawasan; kurangnya SDM baik secara kuantitas maupun kualitas; struktur birokrasi yang belum memadai. Hal ini berdampak pada belum optimalnya implementasi PKMA-APIP guna memberikan jaminan dan memastikan bahwa audit dilaksanakan sesuai standar yang berlaku.

Komitmen Organisasi dari seluruh unsur yang ada pada Inspektorat Daerah Kabupaten Bone Bolango serta integritas auditor akan berakibat positif dalam menghadapi kendala ini. Selain itu, sumber daya manusia baik secara kuantitas maupun kualitas, serta struktur birokrasi yang memadai, juga sangat penting untuk keberhasilan implementasi PKMA-APIP ini. Untuk itu upaya Inspektorat Kabupaten Bone Bolango dalam mengatasi kendala-kendala yang ada haruslah lebih optimal agar implementasi PKMA-APIP guna memastikan dan menjamin kualitas audit dapat terwujud. Model analisis penelitian ini dapat digambarkan sebagai berikut:

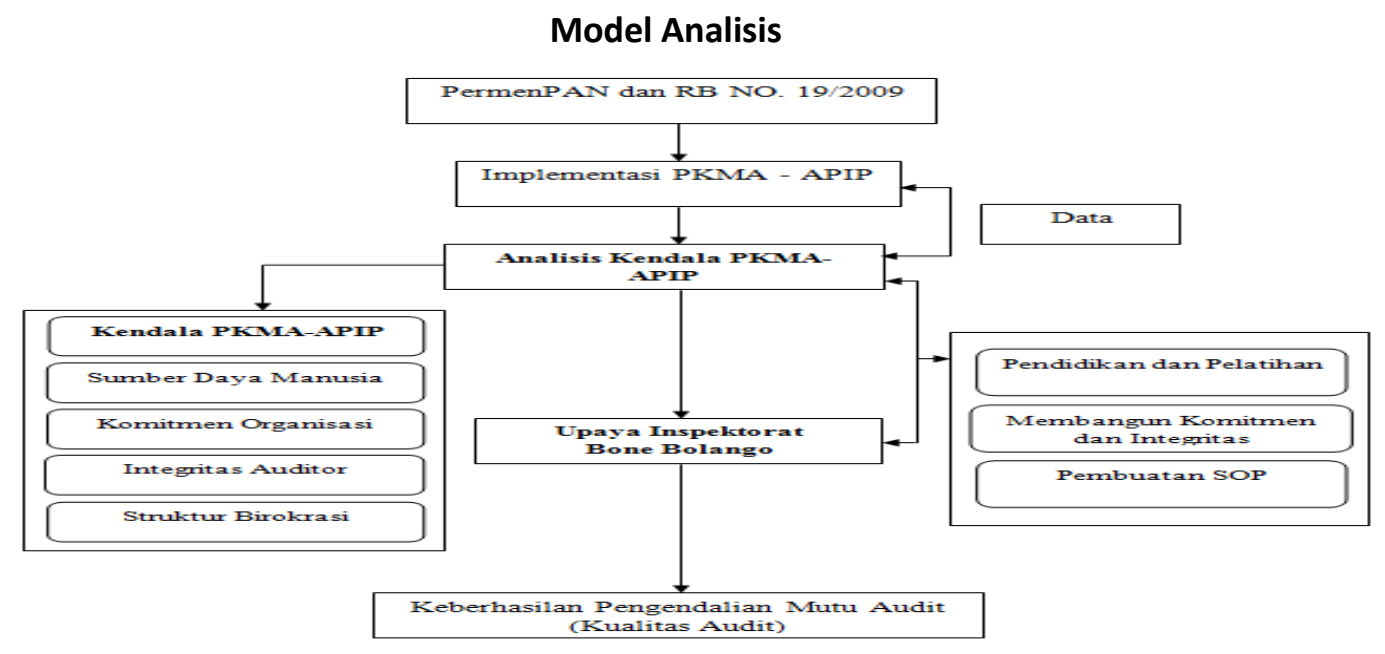

\section{Hasil Penelitian dan Pembahasan}

Pedoman Kendali Mutu Audit Aparat Pengawas Intern Pemerintah mulai diterapkan di Inspektorat Derah Kabupaten Bone Bolango sejak tahun 2016. Pada prinsipnya, sebagai pedoman untuk memberikan jaminan dan memastikan bahwa audit yang dilakukan sudah sesuai standar yang berlaku dibutuhkan PKMA-APIP yang dtuangkan dalam Permenpan \& RB No.19/2009, dalam hal ini dijadikan acuan serta dasar dimana aparat pengawasan internal telah melaksanakan tanggung jawab profesionalnya. Dari kedelapan unsur yang menjadi Pedoman Kendali Mutu Audit-APIP, baru sebagian yang diimplementasikan pada Inspektorat Daerah Kabupaten Bone Bolango yaitu Pedoman Kendali Mutu Penyusunan Rencana dan Program Kerja Audit, Pedoman Kendali Mutu Pelaksanaan Audit, Pedoman Kendali Mutu Pelaporan Audit serta Pedoman Kendali Mutu Tata usaha dan Sumber Daya Manusia. Dan sebagian lagi belum diimplementasikan yaitu Pedoman perencanaan strategi, Pedoman penyusunan rencana audit APIP, Pedoman supervisi audit, serta Pedoman pemantauan tindak lanjut hasil audit.

\section{Analisis Kendala Implementasi Pedoman Kendali Mutu Audit-APIP pada Inspektorat Daerah Kabupaten Bone Bolango}

\section{Komitmen Organisasi}

Untuk mendukung Implementasi PKMA-APIP pada Inspektorat Daerah Kabupaten Bone Bolango dibutuhkan komitmen organisasi yang kuat. Dalam penelitian ini salah satu kendala implementasi PKMA-APIP adalah kurangnya dukungan dan komitmen baik dari pimpinan maupun seluruh personil pengawas untuk melaksanakannya. Komitmen pada dasarnya adalah merupakan kesediaan seseorang untuk mengikatkan diri dan menunjukkan loyalitas pada organisasi karena merasakan dirinya terlibat dalam kegiatan organisasi (Wibowo, 2013:188). Senada dengan itu, Edward III (1980) dalam Mulyadi (2016) menjelaskan bahwa apabila diharapkan implementasi 
kebijakan dapat berjalan secara efektif, maka yang harus bertanggungjawab terhadap implementasi sebuah kebijakan harus mengetahui apa yang harus dilakukannya. Dapat dikatakan bahwa dalam mengimplementasikan PKMA-APIP dibutuhkan kerja sama semua pihak melalui keterlibatan pimpinan atau atasan langsung. Edison et al. (2016:90), keberhasilan dan kegagalan organisasi sebagian besar ditentukan oleh pemimpin sesuai dengan wilayahnya dan seharusnya dia bertanggung jawab atas keberhasilan ataupun kegagalan. Kegagalan dalam mewujudkan apa yang sudah menjadi komitmen atau tekad disebabkan beberapa faktor diantaranya: (1) pembuat yang sudah dicapai; (2) pada level fungsional tidak mampu menjabarkannya secara baik apa yang sudah menjadi komitmen dan/atau tidak memiliki kompetensi untuk melaksanakannya; (3) komitmen yang dibuat tidak didasarkan konsensus yang jelas; (4) meskipun ada konsensus tapi tidak konsisten dijalankan dan tidak memiliki konsekuensi apa-apa (Edison et al. 2014:223).

\section{Sumber Daya Manusia}

Hal lain yang merupakan kendala dalam Implementasi Pedoman Kendali Mutu Audit-APIP pada Inspektorat Daerah Kabupaten Bone Bolango adalah Sumber daya manusia. Sumber Daya adalah faktor penting untuk implementasi kebijakan agar efektif baik secara kualitas maupun kuantitas. Komponen sumber daya manusia meliputi jumlah aparat pengawas, keahlian dari para aparat pengawas sebagai pelaksana, informasi yang relevan, serta cukup untuk menerapkan kebijakan dan pemenuhan sumber-sumber terkait dalam pelaksanaan kebijakan.

Berdasarkan hasil penelitian yang dilakukan terdapat sedikitnya 2 (dua) aspek yang sangat berperan sehingga SDM menjadi salah satu kendala Implementasi Pedoman Kendali Mutu Audit-APIP pada Inspektorat Daerah Kabupaten Bone Bolango. Pertama, kualitas SDM; masih banyak para Aparat Pengawas Intern Pemerintah yang belum memiliki kompetensi (keahlian dan pengetahuan) sehingga mengakibatkan mereka kurang paham akan tugasnya. Kompetensi merupakan karakteristik dasar seseorang yang mengindikasikan cara berpikir, bersikap, dan bertindak serta menarik kesimpulan yang dapat dilakukan dan dipertahankan oleh seseorang pada periode tertentu. Dari karakteristik dasar tanpa tujuan penentuan tingkat kompetensi/standar kompetensi yang dapat mengetahui tingkat kinerja yang diharapkan dan mengkategorikan tingkat tinggi/di bawah rata-rata. Penentuan ambang kompetensi sangat dibutuhkan dan penting, karena dapat dijadikan dasar pertimbangan proses rekruitmen, seleksi, perencanaan, evaluasi kinerja, dan pengembangan sumber daya manusia lain (Sedarmayanti, 2011:346).

Aspek yang kedua, Kuantitas SDM; implementasi Pedoman Kendali Mutu Audit-APIP membutuhkan jumlah sumber daya manusia yang cukup memadai. Jumlah tenaga Aparat Pengawas (Auditor) yang masih minim, yang jika dibandingkan dengan jumlah obyek pengawasan yang begitu banyak merupakan salah satu aspek kendala dalam mengimplementasikan PKMA-APIP yang sepenuhnya belum sesuai dengan Permenpan dan RB No.19 Tahun 2009. Senada dengan Edward III (1980) dalam Teori Implementasi Kebijakan mengatakan bahwa sumber daya manusia yang tidak memadai (jumlah dan kemampuan) berakibat tidak dapat dilaksanakannya kebijakan secara sempurna serta tidak mampu melakukan pengawasan dengan baik. Jika jumlah staf pelaksana kebijakan terbatas, maka hal yang harus dilakukan adalah meningkatkan kemampuan/keterampilan para pelaksana untuk melakukan penerapan kebijakan. Untuk itu, perlu adanya manajemen SDM yang baik agar dapat meningkatkan kinerjanya.

\section{Integritas Auditor}

Kendala berikut dalam implementasi PKMA-APIP yang sepenuhnya belum sesuai dengan Permenpan dan RB No.19 Tahun 2009 pada Inspektorat Daerah Kabupaten Bone Bolango adalah kurangnya integritas auditor atau aparat pengawasnya. Dalam hal ini tanggungjawab terhadap tugas yang diberikan oleh pimpinan APIP. Dalam Kode Etik Aparat Pengawasan Intern Pemerintah yang dituangkan dalam Peraturan Menteri Pendayagunaan Aparatur Negara Nomor :PER/04/M.PAN/03/2008, dikatakan bahwa seorang auditor harus memiliki integritas.

Integritas adalah kepribadian yang dilandasi oleh unsur jujur, berani, bijaksana, dan bertanggung jawab untuk membangun kepercayaan guna memberikan dasar bagi pengambilan keputusan yang andal. Hal ini didukung juga oleh Edward III (1980), dalam teori Implementasi kebijakan yang mengatakan bahwa Penerapan kebijakan harus didukung oleh nilai-nilai dari aparatur 
pelaksana kebijakan, sehingga penerapan kebijakan dapat berjalan efektif. Nilai-nilai pendukung yang hendaknya dimiliki oleh aparatur pelaksana kebijakan adalah Integritas dalam hal ini adalah berpikir, berkata, berperilaku, dan bertindak dengan baik dan benar serta memegang teguh kode etik dan prinsip-prinsip moral.

\section{Struktur Birokrasi}

Faktor kendala yang berikut dalam mengimplementasikan Pedoman Kendali Mutu Audit (PKMA-APIP) yang sepenuhnya sesuai dengan Permenpan dan RB No.19 Tahun 2009 adalah struktur birokrasi. Struktur Birokrasi adalah karakteristik, norma-norma dan pola-pola hubungan yang terjadi berulang-ulang dalam badan eksekutif yang mempunyai hubungan baik potensial maupun nyata dengan apa yang mereka miliki dalam menjalankan kebijakan.

Kebijakan yang kompleks membutuhkan kerjasama banyak orang. Unsur yang mungkin berpengaruh terhadap suatu organisasi dalam penerapan kebijakan salah satunya adalah tingkat pengawasan hirarkis terhadap keputusan-keputusan sub unit dan proses-proses dalam badan pelaksana (Edward III, 1980). Salah satu dari aspek struktur yang penting dari setiap organisasi adalah adanya prosedur operasi yang standar (standard operating procedures atau SOP). SOP menjadi pedoman bagi setiap implementor dalam bertindak. Implementasi PKMA-APIP di Inspektorat Daerah Kabupaten Bone Bolango belum semuanya dituangkan dalam SOP. Kebijakan yang kompleks membutuhkan kerjasama banyak orang. Unsur yang mungkin berpengaruh terhadap suatu organisasi dalam penerapan kebijakan salah satunya adalah tingkat pengawasan hirarkis terhadap keputusankeputusan sub unit dan proses-proses dalam badan pelaksana (Edward III, 1980).

\section{Upaya Mengatasi Kendala Implementasi PKMA-APIP}

Untuk mengimplementasikan Pedoman Kendali Mutu Audit-APIP pada Inspektorat Daerah Kabupaten Bone Bolango yang sepenuhnya sesuai dengan Peraturan Menteri Pendayagunaan Aparatur Negara dan Reformasi Birokrasi Nomor 19 Tahun 2009 tentang PKMA-APIP. Maka dilakukan beberapa upaya dalam mengatasi kendala yang ada pada Inspektorat Daerah Kabupaten Bone Bolango.

Dari hasil wawancara, observasi, dan studi dokumentasi, diperoleh beberapa upaya dalam mengimplementasikan PKMA-APIP dimana Inspektorat Daerah Kabupaten Bone Bolango melakukan pengembangan pendidikan dan pelatihan berkelanjutan bagi para aparat pengawasnya dalam meningkatkan kompetensi serta keahlian yang dimiliki dengan harapan pelaksanaan audit menjadi lebih berkualitas baik melalui pendidikan dan pelatihan auditor, konferensi, seminar, kursus-kursus, program pelatihan dikantor sendiri dan partisipasi dalam proyek penelitian yang memiliki substansi dibidang pengawasan.

Demikian juga halnya dengan upaya yang dilakukan Inspektorat Daerah Kabupaten Bone Bolango untuk membuat prosedur yang disediakan dalam menunjang pelaksanaan tugas dan fungsinya yang belum memadai. Prosedur yang harus dibuat dalam mengimplementasikan Pedoman Kendali Mutu Audit-APIP. Prosedur yang harus disediakan yaitu SOP Penyusunan Renstra, SOP Tahapan Perencanaan, SOP Supervisi Audit, SOP Pemantauan Tindak lanjut.

Kemudian upaya untuk implementasi pengendalian Mutu Audit di Inspektorat Kabupaten Bone Bolango adalah adanya usaha membangun komitmen dari seluruh jajaran pimpinan dan staf untuk meningkatkan kualitas audit, serta membangun integritas yang tinggi untuk menunjang pelaksanaan pemeriksaan.

Menurut Sedarmayanti (2016:187), pelatihan dan pengembangan merupakan usaha mengurangi atau menghilangkan terjadinya kesenjangan antara kemampuan karyawan dengan yang dikehendaki organisasi. Usaha tersebut dilakukan melalui peningkatan kemampuan kerja yang dimiliki karyawan dengan cara menambah pengetahuan dan keterampilan serta merubah sikap. Karyawan merupakan kekayaan organisasi yang paling berharga, karena dengan segala potensi yang dimilikinya, karyawan dapat terus dilatih dan dikembangkan, sehingga dapat lebih berdaya guna, prestasinya menjadi semakin optimal untuk mencapai tujuan organisasi. 
Adanya kesenjangan antara kemampuan karyawan dengan yang dikehendaki Organisasi, menyebabkan perlunya organisasi menjembatani kesenjangan tersebut, salah atu caranya pelatihan dan pengembangan. Dengan demikian diharapkan seluruh potensi yang dimiliki karyawan, yaitu pengetahuan, keterampilan dan sikap dapat ditingkatkan, akhirnya kesenjangan berkurang atau tidak terjadi lagi kesenjangan.

Menurut Nawawi (2006:319) pelatihan adalah proses memberikan bantuan bagi para pekerja/anggota organisasi untuk menguasai keterampilan/ keahlian khusus atau memperbaiki kekurangannya dalam melaksanakan pekerjaan. Sedangkan pengembangan adalah proses membantu karyawan/anggota oganisasi dalam meningkatkan sikap, wawasan, kepemimpinan dan penyaluran kemampuan potensial, sebagai persiapan untuk mengantisipasi tantangan masa depan.

Dalam Instruksi Presiden Nomor 15 Tahun 1974, pelatihan adalah bagian dari pendidikan menyangkut proses belajar untuk memperoleh dan meningkatkan keterampilan diluar sistem pendidikan yang berlaku, dalam waktu yang relatif singkat dan dengan metode yang lebih mengutamakan praktek daripada teori. Pelatihan adalah proses pembelajaran yang lebih menekankan pada praktek daripada teori yang dilakukan seseorang atau sekelompok dengan menggunakan pendekatan pelatihan untuk orang dewasa dan bertujuan meningkatkan dalam satu atau beberapa jenis keterampilan tertentu (SK Menpan Nomor 01/Kep/M.Pan/2001).

Menurut Edwin B. Flippo dalam Sedarmayanti (2016:188), pelatihan adalah proses membantu pegawai memperoleh efektivitas dalam pekerjaan sekarang atau yang akan datang melalui pengembangan kebiasaan, pikiran dan tindakan, kecakapan, pengetahuan dan sikap. Sementara menurut Andrew E. Sikula dalam Sedarmayanti (2016:188), "training is a short-term educational process utilizing a systematic and organized procedure by with non managerial personel learn technical knowledge and skills for definite purpose. Development is a long-term educational process utilizing a systematic and organized procedure by which managerial personnel learn conceptual and theoretical knowledge for general purpose". (Pelatihan adalah suatu proses pendidikan jangka pendek memanfaatkan prosedur yang sistematis dan terorganisir, dimana personil non manajerial mempelajari kemampuan dan pengetahuan teknis untuk tujuan tertentu. pengembangan adalah suatu proses pendidikan jangka panjang memanfaatkan prosedur sistematis dan terorganisir, dimana personil manajerial mempelajari pengetahuan konseptual dan teoritis untuk tujuan umum).

Menurut Keith Davis dan William B.,Werther, Jr dalam Sedarmayanti (2016:188), "training prepares people to do their present job and deveopment prepares employees needed knowlegde, skill and attitude". (Pelatihan mempersiapkan orang untuk melakukan pekerjaan mereka sekarang dan pengembangan mempersiapkan pegawai yang membutuhkan pengetahuan, keterampilan, dan sikap). Dalam Sedarmayanti (2016:25) dijelaskan bahwa keahlian teknik psikologis sering diterapkan dalam desain dan impelementasi program jangka pendek, antara lain:

1) Recruiting: menggunakan keahlian psikologis dalam rangka mempengaruhi ukuran dan kualitas calon SDM;

2) Selection: untuk meningkatkan program rekrutmen;

3) Appraisal: untuk mengidentifikasi kemampuan kinerja yang digunakan untuk penghargaan;

4) Training: untuk pengembangan keahlian SDM;

5) Compensation: untuk penggajian, menarik SDM baru, memotivasi dan mempertahankan SDM agar lebih produktif.

Dalam Sedarmayanti (2016:158), pelatihan berdasarkan kompetensi (Competency Based Training/CBT) adalah pelatihan yang didasarkan atas hal yang diharapkan dapat dilakukan seseorang di tempat kerja. Hal ini secara luas diterima di manca negara, dan merupakan salah satu cara untuk membuat pelatihan lebih relevan terhadap dunia kerja. CBT memberi tekanan pada apa yang dapat dilakukan oleh seseorang sebagai hasil pelatihan (output). Hal ini berbeda dengan pendekatan tradisional yang lebih memberi tekanan pada jumlah kehadiran dalam pelatihan (input).

Manfaat CBT untuk peserta adalah:

1) Memberi kesempatan bagi peserta untuk belajar mengembangkan keterampilan dengan tingkat kecepatan berbeda dan dengan cara berbeda;

2) Memungkinkan peserta bersikap lebih bertanggungjawab terhadap kemajuannya; 
3) Memotivasi peserta;

4) Membuat peserta aktif dan dapat memusatkan perhatian pada tugasnya.

Menurut Suwatno dan Donni Juni Priansa (2016:103), pengembangan (development) diartikan sebagai penyiapan individu untuk memikul tanggungjawab yang berada atau lebih tinggi didalam organisasi. Pengembangan biasanya behubungan dengan peningkatan kemampuan intelektual atau emosional yang diperlukan untuk menunaikan pekerjaan yang lebih baik. Selanjutnya Suwatno dan Donni Juni Priansa (2016:105) menegaskan bahwa pengembangan pegawai merupakan aktivitas memelihara dan meningkatkan kompetensi pegawai guna mencapai efektivitas organisasi. Pengembangan pegawai dapat diwujudkan melalui pengembangan karier, serta pendidikan dan pelatihan. Pengembangan karyawan adalah aktivitas memelihara dan meningkatkan kompetensi pegawai guna mencapai efektivitas organisasi.

Menurut Suwatno dan Donni Juni Priansa (2016:118), pelatihan berarti suatu perubahan yang sistematis dari knowledge, attitude dan behaviour yang terus mengalami peningkatan yang dimiliki oleh setiap karyawan dengan itu dapat mewujudkan sasaran yang ingin dicapai oleh suatu organisasi atau perusahaan dalam pemenuhan standar SDM yang diinginkan. Learning atau pembelajaran didefinisikan oleh Greenberg dan Baron dalam Wibowo $2015: 147)$ sebagai perubahan yang relatif permanen dalam perilaku yang terjadi sebagai hasil pengalaman. Pembelajaran memerlukan terjadinya beberapa macam perubahan yang terjadi tidak bersifat sementara dan sebagai hasil dari pengalaman.

Berdasarkan uraian-uraian di atas secara keseluruhan dapat disimpulkan bahwa implementasi PKMA-APIP pada Inspektorat Kabupaten Bone Bolango dapat dilaksanakan sepenuhnya sesuai dengan Permenpan No.19/2009 apabila didukung oleh seluruh komponen yang ada, baik dalam membangun komitmen organisasi maupun integritas dengan sumber daya manusia yang berkualitas serta didukung dengan struktur birokrasi yang memadai. Kurnia (2016) dalam penelitiannya menghasilkan bahwa strategi yang digunakan untuk meningkatkan kendali mutu audit adalah peningkatan kompetensi auditor melalui diklat, penambahan jumlah auditor, dukungan dan komitmen pimpinan dan seluruh personil pengawas untuk melaksanakan prosedur PKMA-APIP.

\section{Kesimpulan}

Berdasarkan hasil analisis terhadap kondisi yang dijumpai dalam penelitian seperti dibahas dalam bab sebelumnya, maka kesimpulan yang dapat ditarik dalam penelitian ini adalah Implementasi Pedoman Kendali Mutu Audit-Aparat Pengawas Intern Pemerintah (APIP) di Inspektorat Daerah Kabupaten Bone Bolango belum sepenuhnya sesuai dengan Permenpan No.19 Tahun 2009 tentang PKMA-APIP. Hal ini disebabkan karena:

1. Inspektorat Daerah Kabupaten Bone Bolango memiliki kendala dalam mengimplementasikan PKMA-APIP yaitu:

a. Komitmen organisasi, dimana masih kurangnya dukungan dari pimpinan dan aparat pengawas dalam mengimplementasikan PKMA-APIP yang sepenuhnya sesuai dengan Permenpan No.19 Tahun 2009.

b. Sumber daya manusia yang belum memadai baik secara kualitas (pengetahuan dan keahlian) maupun kuantitas yakni jumlah Auditor yang masih minim yang tidak sesuai dengan jumlah objek pemeriksaan.

c. Integritas auditor yang masih kurang, dimana dalam hal tanggungjawab terhadap tugas yang diberikan oleh pimpinan APIP yang kadang dilaksanakan sehingga menyebabkan pelaksanaan tugas dalam bidang pengawasan guna pencapaian kulitas audit belum optimal.

d. Struktur birokrasi belum memadai, yaitu salah satu dari aspek struktur yang penting dari setiap organisasi adalah adanya prosedur operasi yang standar (standard operating procedures atau SOP). Dari delapan unsur PKMA-APIP baru sebagian dituangkan dalam Standar Operasional Prosedur (SOP), dan sebagian lagi belum dibuat yakni Standar Operasional Prosedur (SOP) Penyusunan Rentra, SOP Perencanaan audit APIP, SOP Supervisi audit, serta SOP Tindak lanjut hasil audit. 
2 Upaya yang dilakukan Inspektorat Daerah Kabupaten Bone Bolango dalam mengatasi kendala dalam mengimplementasikan PKMA-APIP yaitu:

a. Upaya membangun komitmen Organisasi baik dari jajaran staf dan pimpinan agar dapat mengimplementasikan PKMA-APIP sesuai dengan prosedur yang ditetapkan.

b. Upaya yang dilakukan adalah pengembangan kompetensi (keahlian dan pengetahuan) aparat pengawas melalui diklat-diklat pengawasan dan bimtek pengawasan sehingga dapat menciptakan SDM yang dapat memahami tugas yang diberikan.

c. Upaya membangun integritas aparat pengawas agar dapat menjaga sikap dan prilaku serta tanggungjawab dalam pelaksanaan tugas pengawasan yang sesuai dengan PKMA-APIP.

d. Upaya membuat prosedur (SOP) sesuai dengan PKMA-APIP yang dapat digunakan sebagai pedoman pelaksanaan tugas pengawasan.

\section{Saran}

Untuk dapat mengimplementasikan Pedoman Kendali Mutu Audit (PKMA-APIP) yang sepenuhnya sesuai dengan Permenpan No.19 Tahun 2009, ada beberapa hal yang dapat disarankan untuk menjadi perhatian demi perbaikan ke depan antara lain:

1. Inspektorat Kabupaten Bone Bolango baik pimpinan maupun jajaran dibawahnya agar berkomitmen untuk melaksanakan pemeriksaan sesuai dengan peraturan yang berlaku demi tercapainya kualitas pemeriksaan yang lebih baik, juga dalam hal integritas (tanggungjawab) auditornya dalam melakukan pemantauan efektifitas pelaksanaan program dan pengendalian mutu audit, sehingga diperoleh jaminan bahwa audit yang dilaksanakan oleh Inspektorat Dearah Kabupaten Bone Bolango telah memenuhi Standar Audit APIP.

2. Inspektorat Kabupaten Bone Bolango dalam mengimplementasikan, mempertahankan dan atau meningkatkan mutu audit, guna peningkatan SDM harus memelihara kompetensi auditornya melalui pendidikan profesional berkelanjutan, yaitu diikutsertakan pelatihan, diklat-diklat pengawasan, serta bimtek pengawasan. Keterbatasan sumber daya pengawas atau auditornya, APIP dapat mengambil calon dari dalam organisasi ataupun dari luar organisasi. Pengambilan dari dalam organisasi akan memudahkan penyesuaian karena calon auditor yang bersangkutan telah mengenal organisasi dengan baik dan telah mempunyai pengalaman sebagai pelaksana, serta melakukan penilaian kinerja auditor secara periodic sehingga menimbulkan motivasi untuk meningkatkan kompetensi diri.

3. Inspektorat Daerah Kabupaten Bone Bolango harus mengatur dengan jelas dan menetapkan Standar Operational Prosedur (SOP) Pedoman Kendali Mutu Audit (PKMA-APIP) untuk menjamin kualitas audit. Yaitu Standar Operasional Prosedur (SOP) Penyusunan Rentra, SOP Perencanaan audit APIP, SOP Supervisi audit, serta SOP Tindak lanjut hasil audit. Karena salah satu dari aspek struktur yang penting dari setiap organisasi adalah adanya prosedur operasi yang standar (standard operating procedures atau SOP).

4. Untuk penelitian selanjutnya, supaya lebih menggali topik atau tema-tema yang lain sehubungan dengan Implementasi PKMA-APIP selain kendala, mekanisme pelaksanaan atau pengendalian internal.

\section{Daftar Pustaka}

Andayani, Tri. 2009. Analisa Program Jaminan Kualitas Audit di Lingkungan Inpektorat Jenderal Departemen Hukum dan HAM RI. Tesis Program Studi Magister Manajemen Kekhususan Akuntansi Pemerintahan Binus University Jakarta.

Asosiasi Auditor Intern Pemerintah Indonesia (AAIPI). 2013. Standar Audit Intern Pemerintah Indonesia. Jakarta.

Creswell, Jhon.,W. 2014. Penelitian Kualitatif dan Desain Riset. Pustaka Pelajar. Yogyakarta.

Edison, E., Anwar, Y.,Komariah, J. 2016. Manajemen Sumber daya Manusia, Strategi dan Perubahan dalam rangka meningkatkan kinerja pegawai dan Organisasi. Alfabeta : Bandung.

Edward, George C. III. 1980. "Implementing Public Policy". Washington DC: Congresional, Quartely Press. 
Denzin, N. K and Lincoln. Y.S 2005. The Sage Handbook of Qualitative Research, Third Edition, Thousand Ooks. California: Sage Publication Inc.

Halim Abdul, 1995. Auditing I (Dasar-dasar Audit laporan Keuangan). UGM. Yogyakarta.

Ismail, Aida Hazlin, Zuraidah Mohd-Sanusi, Yusarina Mat Isa, Syazliana Kasim, Kamaruzaman Muhamad and Nor'Azam Mastuki. 2008. Implementation of Audit Quality Control System: Preliminary Evidence From Small And Medium Audit Practices In Malaysia. Universiti Teknologi MARA Faculty of Accountancy Shah Alam, Malaysia. The 9th Asian Academic Accounting Association Annual Conference Dubai, United Arab Emirates.

Instruksi Presiden Republik Indonesia No.15 Tahun 1974 Tentang Pokok-pokok Pelaksanaan Pembinaan Pendidikan dan Latihan.

Kurnia, Marisa. N. A. 2016. Analisis pengendalian Mutu Audit Pada Inspektorat Kabupaten Merangin Jambi.

Laporan Hasil Penilaian Quality Assurance Tahun 2016 Oleh BPKP Perwakilan Provinsi Gorontalo.

Mahmudi. 2011. Akuntansi Sektor Publik. Edisi pertama. UII Press: Yogyakarta.

Mulyadi, Dedy. 2016. Studi Kebijakan Publik dan Pelayanan Publik. Alfabeta. Bandung.

Nawawi, Hadari. 2006. Kepemimpinan Mengefektifkan Organisasi, Cetakan Ke-2, Gadjah Mada University Press, Yogyakarta.

Peraturan Bupati Bone Bolango No.11 tahun 2015 tentang Pembentukan Organisasi dan Tata Kerja Inspektorat, Badan Perencanaan Pembangunan Daerah Kabupaten Bone Bolango.

Peraturan Bupati Bone Bolango No.13 Tahun 2010 tentang Uraian Tugas Inspektorat Daerah Kabupaten Bone Bolango.

Peraturan Bupati Bone Bolango No.288 Tahun 2015 tentang Program Kerja Pengawasan Tahunan Inspektorat Daerah Kabupaten Bone Bolango.

Peraturan BPKP. 2008. Kode Etik dan Standar Audit. Edisi Kelima. Diklat Pembentukan Auditor Ahli.

Peraturan Menteri Pendayagunaan Aparatur Negara Nomor PER/04/M.PAN/03/2008 tentang Kode Etik Aparat Pengawas Intern Pemerintah.

Peraturan Menteri Pendayagunaan Aparatur Negara Nomor PER/05/M.PAN/03/2008 tentang Standar Audit Aparat Pengawas Intern Pemerintah.

Peraturan Menteri Negara Pendayagunaan Aparatur Negara dan Reformasi Birokrasi (PermenPAN dan RB) Nomor 19 Tahun 2009 tentang Pedoman Kendali Mutu Audit - APIP.

Peraturan BPK-RI Nomor 1 Tahun 2007 tentang Standar Pemeriksaan Keuangan Negara (SPKN).

Suwatno, dan Donni Juni Priansa, 2016. Manajemen SDM, Dalam Organisasi Publik dan Bisnis, Cetakan Ke-5, Alfabeta, Bandung.

Sedarmayanti. 2011. Membangun dan mengembangkan kepemimpinan serta meningkatkan kinerja untuk meraih keberhasilan. Bandung PT. Refika Aditama.

Sedarmayanti, 2016. Manajemen Sumber Daya Manusia, Reformasi Birokrasi dan Manajemen Pengawai Negeri Sipil, Edisi Revisi, Bandung Cetakan Ke-5, PT. Refika Aditama.

Sugiyono. 2015. Metode Penelitian Kuantitatif Kualitatif dan R\&D. Cetakan Ke-4. Alfabeta. Bandung. Sujarweni Wiratna, 2015. Akuntansi Sektor Publik. Pustaka Baru Press. Yogyakarta.

Wibowo, 2013. Perilaku Dalam Organisasi. Edisi Pertama, Cetakan Ke-1, PT. Raja Grafindo Persada. Jakarta.

Wibowo, 2015, Perilaku Dalam Organisasi. Edisi Kedua, Cetakan Ke-3, Rajawali Pers. Jakarta. 